\title{
"Impact of functional interdependency on employee satisfaction with performance appraisal in the real estate industry"
}

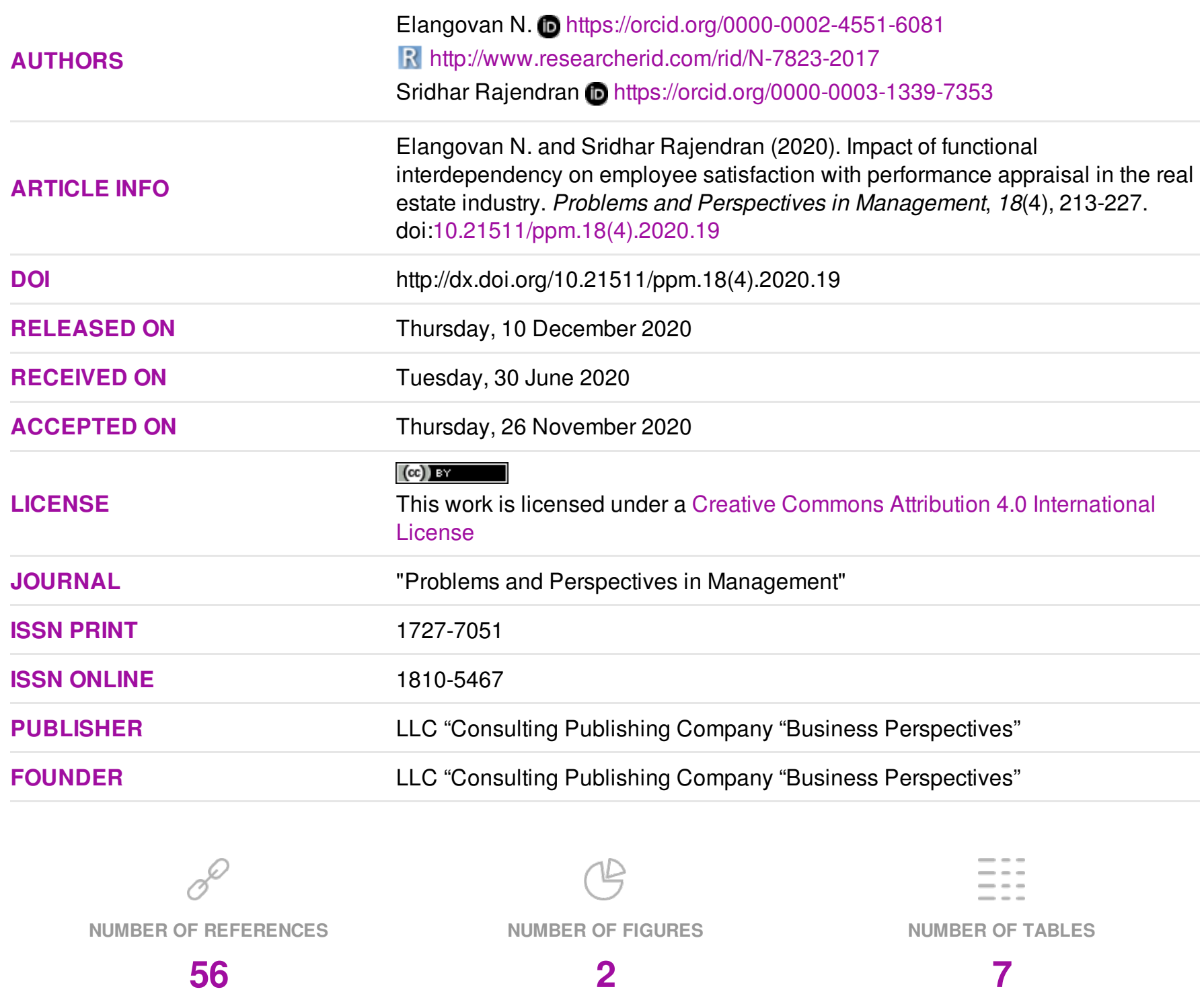

(C) The author(s) 2023. This publication is an open access article. 


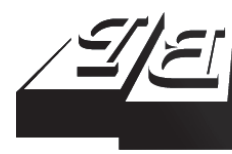

BUSINESS PERSPECTIVES

(

LLC "CPC "Business Perspectives"

Hryhorii Skovoroda lane, 10,

Sumy, 40022, Ukraine

www.businessperspectives.org
Received on: $30^{\text {th }}$ of June, 2020

Accepted on: $26^{\text {th }}$ of November, 2020

Published on: $10^{\text {th }}$ of December, 2020

(C) Elangovan N.,

Sridhar Rajendran, 2020

Elangovan N., Ph.D., Associate Professor, School of Business and Management, Christ University, India. (Corresponding author)

Sridhar Rajendran, Research Scholar, School of Business and Management, Christ University, India.

\section{IMPACT OF FUNCTIONAL INTERDEPENDENCY ON EMPLOYEE SATISFACTION WITH PERFORMANCE APPRAISAL IN THE REAL ESTATE INDUSTRY}

\begin{abstract}
Unbiased performance appraisal tends to bolster the performance of employees. The studies indicate several inadequacies with the current performance appraisal systems. Functional interdependence is one such factor that has been ignored. The study aims to find the factors that can improve the satisfaction with performance appraisal of employees whose deliverables are highly interdependent on other functions. Organizational justice, rater competence, inter-functional conflict, and cohesion are considered the mediating variables. To test the model, the data are collected through a survey using a questionnaire from the executives of Indian real estate companies who have undergone the appraisal process at least once. Firms with more than 500 employees are randomly selected for the list of members of the real estate developers' associations. The results show that functional interdependency has a negative impact on satisfaction with performance appraisal. Although conflict and cohesion are found to influence satisfaction with performance appraisal, they did not mediate the effect of functional interdependency on satisfaction with performance appraisal. However, the study found that rater competence and organizational justice have a mediating effect. The study provides practical implications to HR managers of real estate companies to train the raters and include the complexities of functional interdependencies in the appraisal system. A grievance mechanism should be created to address the employees' concerns, ultimately improving satisfaction with performance appraisal.
\end{abstract}

Keywords

interdependency, performance, appraisal, satisfaction, rater competence, organizational justice, Indian real estate industry

JEL Classification M12, M54

\section{INTRODUCTION}

There are practical challenges posed by the appraisal process, leaving managers and employees frustrated and dissatisfied. The studies show that performance management in the real estate industry is complicated and requires a systematic and holistic approach. Building a good appraisal system builds mutual trust between the managers and employees. Indian real estate sector suffers from a high attrition rate of around $35 \%$. The real estate sector has been a late adopter of HR practices and is experimenting with new HR practices to retain employees. Real estate companies operate under three major departments: Construction, Sales, and Customer Relationship Management (CRM). Besides, they have support departments like Legal, Finance and Accounts, Business Development or Land Acquisition, Human Resources, and General Administration. The successful outcome of an individual's performance depends on other employees' successful outcomes in various departments. Considering the background of the functional interdependencies existing in real estate companies, employee satisfaction with the outcome of annual appraisal is a question 
because the deliverables are not being measured in the context of the deliverables of the other teams. Building an appraisal system to map the performance of various teams in evaluating individual performance appraisal becomes complex and biased. In such a situation, HR managers find it difficult to resolve the employee's grievances and improve satisfaction with performance appraisal among the employees. Lack of such satisfaction will lead to overall job satisfaction and poor engagement. The researcher's problem is to find out the factors that can improve employee satisfaction with performance appraisal in an interdependent environment. This requires research on various HR aspects of the real estate sector. The current study investigates the factors that can intervene with the performance appraisal process in an interdependent process and increase employee satisfaction.

The main research question is "What factors can improve employee satisfaction with performance appraisal in the real estate industry whose performance is dependent on the output of other departments?" It also leads to further research questions:

1) Do organizational dynamics such as inter-functional cohesion and conflict affect performance appraisal satisfaction among employees who depend more on others' performance?

2) Do appraisal-related factors such as rater competence and organizational justice affect the satisfaction with performance appraisal among employees who depend more on others' performance?

\section{LITERATURE REVIEW, RESEARCH MODEL AND HYPOTHESES}

DeNisi and Murphy (2017) studied the performance appraisal and performance management progress in 100 years through a meta-analysis and identified performance appraisal reaction as one of the eight research areas. They identified little research on reactions to performance appraisals until the 1970s, which mainly focused on ratee satisfaction and perceptions of fairness. Further research studies focused on the role of justice perceptions in reaction to performance appraisal. Keeping and Levy (2000) believed that the assessment of reactions is important because of practitioners' great interest and its relationship to appraisal acceptance and success and claim that "satisfaction has been the most frequently measured appraisal reaction." Appraisal satisfaction was found to confound with perceived fairness, accuracy, and utility. Chen et al. (2011) presented that goal interdependence and procedural justice influence appraisal reactions to workgroups than individual performance appraisal. Bachrach et al. (2006) proposed an impact of task interdependence on organizational citizenship behavior and performance evaluation. This study provides a basic theoretical foundation to the relationship between organizational justice, rater competence, inter-functional cohesion, and conflict with satisfaction with performance appraisal in the inter-functional interdependence situations.

Performance appraisal is one of the most important human resource management functions (Kampkotter \& Marggraf, 2015). As stated by Messmer (2004), many employees do not consider this exercise a genuine and exciting process in their career. The performance appraisal system's success depends on the employees' perception of fairness of the performance appraisal (Erdogan, 2002; Sabeen \& Mehboob, 2008). Even though the employees working in various departments or sectors perform different tasks, their deliverables in the performance affect the performance of the employees in other departments or sectors directly or indirectly. In many cases, the inputs to perform a particular task are the output of another employee's performance in another sector or department. Van der Vegt and Janssen (2003) defined "interdependency is the extent to which an individual team member needs information, materials, and support from other team members to be able to carry out his or her job." They have established that interdependency involves interaction among members. High task interdependence implies the need for intensive interactions among members, creating more opportunities for conflict (Wilmot 
\& Hocker, 2001; Xie, Song, \& Stringfellow, 1998). Non-availability of even one piece of information on time will lead to delay in the deliverables of a team. The question that arises here is whether the existing appraisal processes take care of interdependencies in the performance. Hence, the assumption made in this study is that if there is no coordination, then the employee's job performance is affected.

According to Keeping and Levy (2000), appraisal satisfaction has been the most frequently studied among all performance appraisal reactions. Hence, satisfaction with the performance appraisal process is an important variable in this study. Employee appraisal reactions, i.e., fairness and satisfaction, have been considered imperative for organizations (Cardy \& Dobbins, 1994; Keeping \& Levy, 2000). McDowell and Fletcher (2004) quoted [Boswell and Boudreau (2000)] that "perceptions of fairness of the system are an important aspect that contributes to its effectiveness. Understanding employee attitude about the performance appraisal system in organizations is important, as they can determine its effectiveness." When employees are satisfied with their appraisals, they are likely to be motivated to engage in positive employee behaviors (Kuvaas, 2006). Baethge and Rigotti (2013) proposed that interruptions are negatively related to satisfaction with one's performance. Interruptions to performance may be due to controllable factors internal to the employee or uncontrollable factors external to the employee. Inter-functional interdependence is seen negatively as an interruption in an individual's performance.

Due to the complexity of the job performance and interpersonal relations at work, much of the existing research typically indicate that raters account for significant proportions of the variance in employees' true performance (Woehr et al., 2005; Hoffman \& Woehr, 2009), and analyzing the gaps in the existing appraisal process rater's role acts as a key factor in deciding the fairness on performance appraisal. Thurston and McNall (2010) argued that performance appraisal systems believed that ratings' inaccuracies were due to the deliberate distortion of performance ratings by the raters themselves. Further on, they elaborated that a discrepancy can occur when the performance ap- praisal does not meet an individual's beliefs about the rating he or she should receive. Othman (2014) found that an appraiser's credibility is related to the satisfaction of the performance appraisal system. However, he suggested that a team-based performance appraisal is better than an individual-based performance appraisal. Jawahar (2006) argued that satisfaction with rater correlates with satisfaction with the appraisal system. However, the same needs to be tested in a complex organization with sequential interdependence.

Greenberg (1986) first established the relationship between organizational justice and performance appraisal: "organizational justice implies that fairness is being considered in the organization". Tang and Sarsfield-Baldwin (1996) define organizational justice as "What the decisions are" at the end of the appraisal process, or the "content of fairness". More specifically, the researchers have acknowledged that the relationship between performance appraisal events is a predictor of organizational justice (Cropanzano et al., 2002; Jacobs et al., 2014). "The performance system can be blamed if the criteria for evaluation are poor, the technique used is cumbersome, or the system is more form than substance. Organizational commitment is positively associated with the use of explicit evaluative criteria and openness to discussing the appraisal" (Pettijohn et al., 2001). Cook and Crossman (2004) argued that "the source of satisfaction and/or dissatisfaction with the PAS was not equally attributable to all aspects of organizational justice". At the same time, Palaiologos et al. (2004) proposed that organizational justice impacts employee satisfaction in performance appraisal. Among the three components of organizational justice, they found that procedural and distributive justice has an influence. Therefore, there is a need to test organizational justice in the context of interdependency.

Conflict is an interesting variable that plays a critical role in interdependencies, which decides the employee's performance. When conflict is not well managed, it affects relationship quality (Bobot, 2011). Cross-functional conflict is influenced by the performance of other frontline functions (Arndt et al., 2012). Le Meunier-Fitzhugh and Piercy (2010) describe the inter-functional conflict as "working at cross-purposes, being obstructive and not appreciating each other's roles" and 
contested that "extant of research generally proposes that cross-functional conflict impacts team performance because conflict inhibits joint problem-solving towards a shared goal". Literature reveals mixed results on the benefits and harm of conflict to groups and organizations. Conflict is detrimental to organizational functioning and leads to unnecessary energy drain probing on conflict causes and resolution. However, recently, some researchers have theorized that conflict is beneficial under some circumstances (Tjosvold, 1991). De Dreu and Van Vianen (2001) found that "when there is an avoidant conflict management culture, this increases the levels of both teams functioning and team effectiveness".

Cohesion bundles members of various functions together through positive emotions, and the negative emotions weaken the cohesive relationships. Interdependence theory suggests that individuals will work together to achieve common goals in team settings (Deutsch, 1949). Cohesiveness at the organizational level among various functions represents the degree to which the organization members are aligned to each other to achieve the common goal of the organization, and it ensures developing this cohesion among its members by promoting unbiased reward systems and various employee engagement activities. An inter-functional interdependency improves the deliverables and increases the employee's confidence level by trust, cohesion, and satisfaction among the members of various functions. In this, cohesion is the key construct that describes how members of the same group or members of different groups work together, which eventually impacts the organization's overall outcome. However, a meta-analysis by Gully et al. (1995) identified that cohesion is not always connected with performance in groups with task interdependence.

A critical review of the literature reveals the impact of functional interdependencies on the satisfaction with performance appraisal in the real estate industry and the intervening role of rater competence, organizational justice, functional conflicts, and cohesion in increasing or decreasing the satisfaction. Figure 1 shows the research model framed in this study. The hypotheses are as follows:

H1: Functional interdependency influences satisfaction with performance appraisal.

H2: Rater competence mediates the influence of functional interdependency on satisfaction with performance appraisal.

H3: Organizational justice mediates the influence of functional inter-dependency on satisfaction with performance appraisal.

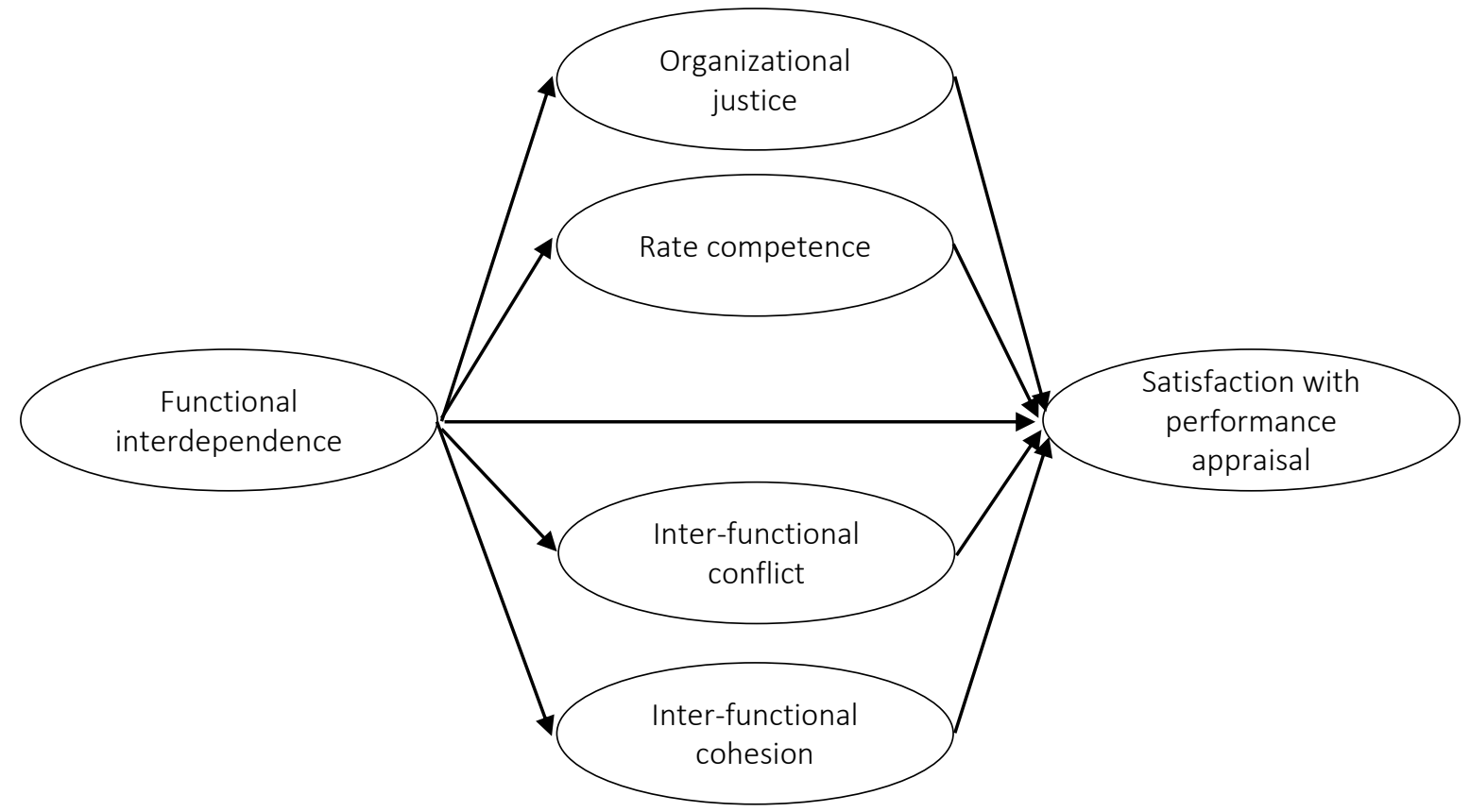

Figure 1. Conceptual model 
H4: Inter-functional conflict mediates the influence of functional inter-dependency on satisfaction with performance appraisal.

H5: Inter-functional cohesion mediates the influence of functional inter-dependency on satisfaction with performance appraisal.

\section{METHODOLOGY}

This study was administered among junior and senior employees working in various real estate companies in India. Employees who have undergone the performance appraisal at least once in their career have been considered for the study. There is no specific data on the number of employees in the construction industry. Therefore, the population is considered to be infinite. Only the list of real estate companies is available; therefore, a multistage sampling is used. First, companies are considered the sampling unit and are selected randomly from the members' list of the Confederation of Real Estate Developers' Association of India (CREDAI). Second, all the executives from the selected real estate companies who fulfilled the qualifying criteria were selected as the sampling unit. This is very similar to cluster sampling. Instead of clusters, random companies were selected as the sampling unit. Around 24 companies were selected from the list of 400 companies with more than 500 employees through a simple random sampling. The period of study was for three months, between March 2017 and May 2017. Considering an infinite population and based on Krejcie and Morgan (1970), a target response of 384 was planned. Accounting for non-responses, 2000 respondents were approached, and the questionnaires were distributed. The survey questionnaire was distributed through Zoho, an online survey platform, which provides the facility to fil- ter out the completed survey questionnaires and eliminate the incomplete survey responses. At the end of the survey, the total number of 464 eligible responses were received. This makes a response rate of $23.2 \%$, which is normal for a survey.

The questionnaire used was developed from the existing standard scales of earlier studies. The items were collected, compiled, and tested for their validity and reliability from the available literature. In the present study, few minor modifications were made in the scale to suit the employees working in real estate companies in India. The instrument was validated at various stages. First, the content and face validity is checked by having the questionnaire reviewed by experts. Three experts from the real estate industry and four experts from the human resource and appraisal background validated the concept and the items of the instrument. Four experts from the academic background validated the structure, language, and suitability of the measurement scales. Eighty-seven items listed originally were reduced to 52 in the final stage. For convergent and divergent validity, using the pilot data collected, statistical analysis was done to check the distribution and the consistency among the scale items. The correlations of the new items and the previous items were checked for suitability. The final instrument had six sections, with a total of 52 items (see Table 1). The demography section measured gender, job grade, educational qualification, and the number of times the employee underwent performance appraisal.

Raw data received from the survey were labeled with a unique identifier, electronically saved, and backed up. The raw data were entered in SPSS with the first column as the assigned unique identifying number to the participant. One row was assigned to each participant. The data were cleaned and coded by the researcher. The data were ana-

Table 1. Items in the measuring instrument

\begin{tabular}{|c|c|c|c|}
\hline Construct & Items & Scale & Source \\
\hline Functional interdependency (FI) & 8 & \multirow{6}{*}{$\begin{array}{l}\text { 5-point Likert } \\
\text { scale }\end{array}$} & Brass, 1981 \\
\hline Inter-functional cohesion (IF-COH) & 9 & & Derozier (2003) \\
\hline Inter-functional conflict (IF-CON) & 8 & & Sun (2011) \\
\hline Rater competence (RC) & 7 & & Walsh (2003) \\
\hline Organizational justice (OJ) & 9 & & Panggabean (2001), Buehler (2006) \\
\hline Satisfaction with performance appraisal (Sat-PA) & 11 & & $\begin{array}{l}\text { Murphy and Balzer (1986), Walsh (2003), Aly and } \\
\text { El-Shanawany (2016) }\end{array}$ \\
\hline
\end{tabular}


lyzed using the SPSS version 22.0 statistical tool. The frequency table and descriptive statistics of demography variables and test variables are presented first. Further tests were done using WarpPLS 6.0 free version of the software. The reliability of the measures was analyzed through Cronbach's alpha values, composite reliability, and AVE. The construct validity was tested from the CFA results using loading and cross-loadings, correlation between constructs, and AVE square. The impact of the variables was assessed through path analysis. Direct and indirect coefficients were analyzed for specific mediators and multiple mediators. The model fitness values were also presented.

\section{RESULTS}

In the sample, $63.6 \%(n=295)$ were men and $36.4 \%$ $(n=169)$ were women. $87.7 \%$ of the respondents had a minimum of two times of experience in the appraisal process, which indicated that employees who participated in the survey had prior experience. $96.5 \%$ of the sample population is highly educated, including $49.1 \%$ of postgraduates and $17.9 \%$ with professional degrees, indicating that the sample population was well educated and could easily understand the researcher's problems. Among 464 participants, $66 \%$ of the employees are either at the mid-management or senior level. This indicates that the participants come with a highly professional experience in their domain and have sufficient performance appraisal process experience.

The mean values of all the interdependency scale items were above 3.0, which shows that the respondents have felt functional interdependencies in their role. The mean values of all the items of the cohesion scale were found to be less than 3.0. The respondents felt less cohesion among their peers. Rater compe- tence measures have a mean value of less than 2.99. Respondents felt that the rater competence was below fairness. The mean values of organizational justice measures were found to be less than 2.50. This shows that respondents felt that organizational justice was low. The measures of conflict variable had a mean value above 2.89 . The respondents have said that they felt conflict among their colleagues. The measures of satisfaction with performance appraisal have a mean value of less than 2.64 . This shows that they were not satisfied with the performance appraisal. The results of the reliability test are presented in Table 2. Cronbach's alpha and composite reliability coefficient values of all the constructs were above 0.9. AVE scores of all constructs were above 0.5 . This shows that the measures were consistent.

The results of loading and cross-loading from WarpPLS are presented in Table 3. The results clearly show that each of the reflective indicators is loaded on their respective constructs. This confirms the measurement model and convergent validity of the measures. The correlation between the inter-functional interdependency, satisfaction with performance appraisal, organizational justice, rater competence, inter-functional cohesion, and inter-functional conflict was calculated and analyzed. The results are presented in Table 3.

The correlations among latent variables are given further.

The correlation between functional interdependency and satisfaction with performance appraisal $(-0.131)$ is weak and negative.

The correlation between interdependency and cohesion (-0.066) and organizational justice (-0.190) is weak and negative.

Table 2. Results of reliability tests

\begin{tabular}{|c|c|c|c|c|}
\hline Construct & $\begin{array}{c}\text { Composite reliability } \\
\text { coefficients }\end{array}$ & $\begin{array}{l}\text { Cronbach's alpha } \\
\text { coefficients }\end{array}$ & $\begin{array}{c}\text { Average variance } \\
\text { extracted }\end{array}$ & $\begin{array}{c}\text { Full collinearity } \\
\text { VIFs }\end{array}$ \\
\hline $\begin{array}{l}\text { Satisfied with the performance } \\
\text { appraisal }\end{array}$ & 0.983 & 0.981 & 0.842 & 1.280 \\
\hline Functional interdependency & 0.945 & 0.933 & 0.684 & 1.181 \\
\hline Inter-functional cohesion & 0.964 & 0.957 & 0.749 & 1.143 \\
\hline Rater competence & 0.922 & 0.901 & 0.630 & 1.460 \\
\hline Organizational justice & 0.969 & 0.964 & 0.777 & 1.400 \\
\hline Conflict & 0.933 & 0.918 & 0.636 & 1.374 \\
\hline
\end{tabular}


Table 3. Correlations among latent variables and square roots of AVEs

\begin{tabular}{|c|c|c|c|c|c|c|}
\hline & SAT-PA & FI & IF-COH & $\mathrm{RC}$ & OJ & IF-CON \\
\hline SAT-FA & 0.918 & & & & & \\
\hline $\mathrm{FI}$ & -0.131 & 0.827 & & & & \\
\hline $\mathrm{IF}-\mathrm{COH}$ & 0.217 & -0.066 & 0.865 & & & \\
\hline $\mathrm{RC}$ & 0.116 & -0.350 & 0.040 & 0.794 & & \\
\hline OJ & 0.455 & -0.190 & 0.341 & 0.089 & 0.882 & \\
\hline IF-CON & -0.097 & 0.250 & 0.021 & -0.526 & -0.095 & 0.758 \\
\hline
\end{tabular}

Note: Square roots of average variances extracted (AVEs) shown on diagonal.

The correlation between interdependency and rater competence $(-0.350)$ is moderate and negative, and between conflict $(0.250)$ is weak and positive.

The correlation between cohesion and satisfaction (0.217) and rater competence and satisfaction (0.166) is weak and positive.

The correlation between organizational justice and satisfaction (0.455) is moderate and positive.

The correlation between conflict and satisfaction $(-0.097)$ is weak and negative.

The correlation between cohesion and rater competence (0.040) and between cohesion and conflict (0.013) is positive but negligible.

The correlation between cohesion and organizational justice (0.341) is moderate and positive.

The correlation between rater competence and organizational justice $(0.089)$ is very low and positive.

The correlation between rater competence and conflict $(-0.526)$ is moderate and negative.

The correlation between organizational justice and conflict $(-0.095)$ is low and negative.

The square root of AVE values for every construct is above the correlation values in the respective column. This shows that each of the constructs is distinct, and the discriminate validity is proved. Path analysis with the mediation effect was done in WarpPLS version 6.0 (Figure 2). The results of the regression coefficients are presented in Table 4.
Table 4. Model estimates

\begin{tabular}{l|c:c:c}
\hline \multicolumn{1}{c|}{ Path from } & Path to & $\begin{array}{c}\text { Path } \\
\text { coefficient }\end{array}$ & P \\
\hline FI & SAT-PA & -0.123 & 0.005 \\
\hdashline FI & IF-COH & -0.102 & 0.017 \\
\hdashline FI & RC & -0.387 & $<0.001$ \\
\hdashline FI & OJ & -0.254 & $<0.001$ \\
\hdashline FI & IF-CON & 0.282 & $<0.001$ \\
\hdashline IF-COH & SAT-PA & 0.122 & 0.006 \\
\hdashline RC & SAT-PA & 0.235 & $<0.001$ \\
\hline OJ & SAT-PA & 0.464 & $<0.001$ \\
\hdashline IF-CON & SAT-PA & -0.053 & 0.138 \\
\hline
\end{tabular}

The interdependence influences satisfaction $(\beta=$ $-0.123, p=0.005)$, cohesion $(\beta=-0.102, p=0.017)$, rater competence $(\beta=-0.387, p<0.001)$ and organisational justice $(\beta=-0.254, p<0.001)$ negatively and significantly. Interdependency influences conflict $(\beta=0.289, p<0.001)$ significantly and positively. Cohesion $(\beta=0.121, p=0.006)$, rater competence $(\beta=0.239, p<0.001)$, organisational justice $(\beta=0.464, p<0.001)$ influence satisfaction significantly and positively.

Conflict does not influences satisfaction $(\beta=$ $-0.053, p=0.138)$. The predictability of the dependent variable is tested with $R$-squared values. The results are presented in Table 5. Satisfaction with performance appraisal is predicted by interdependency, rater competence, organizational justice, conflict, and cohesion to the extent of $38.5 \%$. Interdependency predicts rater competence to the extent of $15 \%$, cohesion to the extent of $1 \%$, organizational justice to the extent of $6.4 \%$, and conflict to the extent of $7.9 \%$. The hypothesized model's fitness is tested using the goodness of fit indices from the WarpPLS version 6.0. The results are presented in Table 6 . The threshold values for assessing the quality of the model are also presented in Table 6. On comparing the threshold values, it 


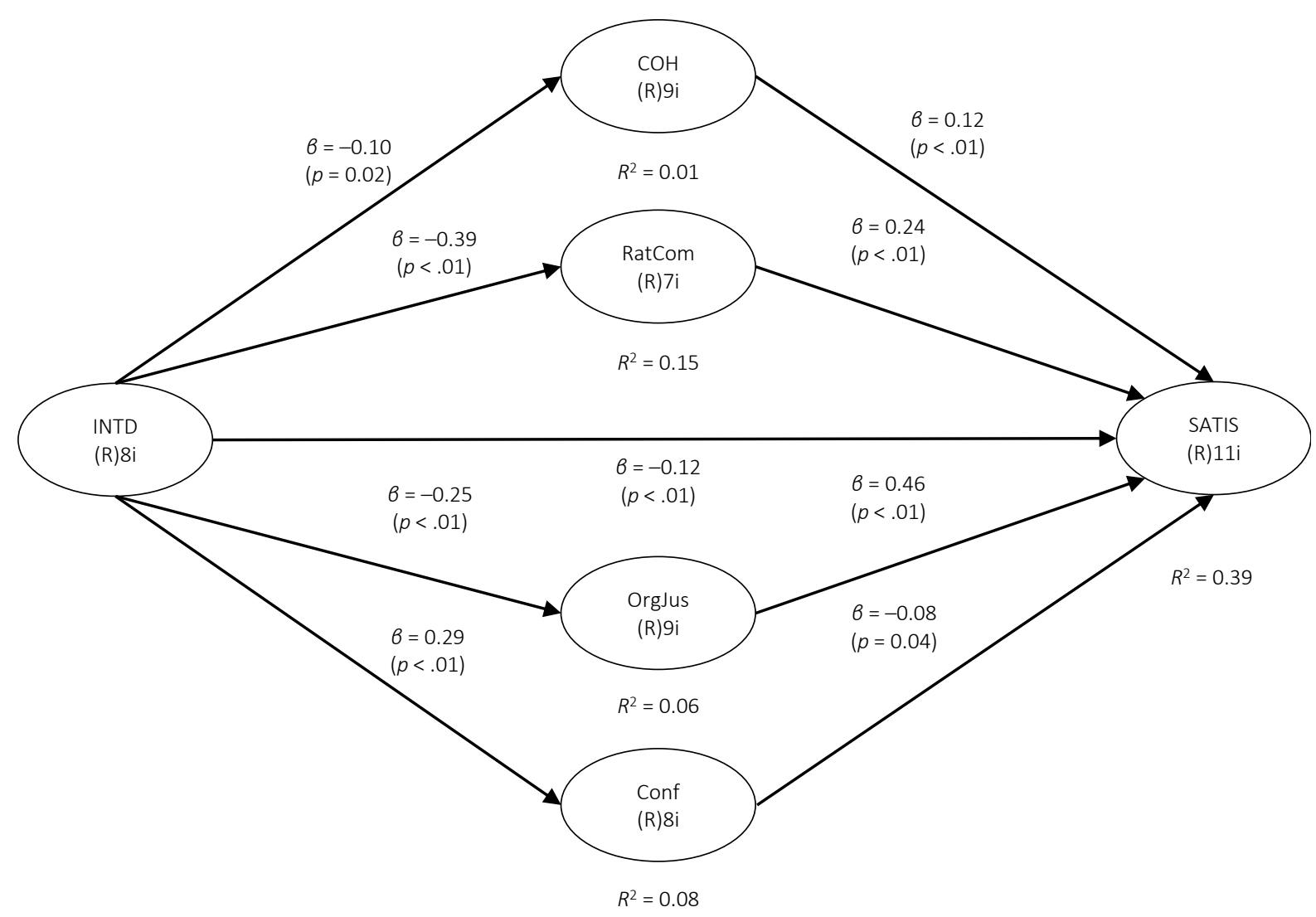

Figure 2. Results of the path analysis

is found that all the fitness values are within the acceptable values. This proves that the proposed model is useful for theorizing.

The overall mediation model with multiple mediators is also tested (Table 7), and it was found that the indirect effect $\beta=-0.236(p<0.001)$, showing that the mediating variables have an impact on the relationship between inter-functional dependency and satisfaction in performance appraisal. The model is found to have better predictability with $R$-squared $=0.385$, and the proposed

Table 5. $R^{2}$ coefficients

\begin{tabular}{l|c|c}
\hline \multicolumn{1}{c}{ Dependent variable } & $\boldsymbol{R}^{\mathbf{2}}$ coefficients & Adjusted $\boldsymbol{R}^{\mathbf{2}}$ coefficients \\
\hline Satisfied with the performance appraisal & 0.385 & 0.378 \\
\hline Cohesion & 0.010 & 0.008 \\
Rater competence & 0.064 & 0.148 \\
Organizational justice & 0.079 & 0.062 \\
\hdashline Conflict & 0.077 & \\
\hline
\end{tabular}

Table 6. Model fit and quality indices

Average path coefficient $(A P C)=0.225, p<0.001$

Average $R^{2}($ ARS $)=0.138, p<0.001$

Average adjusted $R^{2}$ (AARS) $=0.135, p<0.001$

Average block VIF (AVIF) $=1.090$, acceptable if $\leq 5$, ideally $\leq 3.3$

Average full collinearity VIF (AFVIF) $=1.316$, acceptable if $\leq 5$, ideally $\leq 3.3$

Tenenhaus GoF (GoF) $=0.317$, small $\geq 0.1$, medium $\geq 0.25$, large $\geq 0.36$

Sympson's paradox ratio (SPR) $=1.000$, acceptable if $\geq 0.7$, ideally $=1$

$\mathrm{R}^{2}$ contribution ratio $(\mathrm{RSCR})=1.000$, acceptable if $\geq 0.9$, ideally $=1$

Statistical suppression ratio (SSR) $=1.000$, acceptable if $\geq 0.7$

Nonlinear bivariate causality direction ratio (NLBCDR) $=0.722$, acceptable if $\geq 0.7$ 
model has the goodness-of-fit that proves the conceptual model. Though there is an indirect effect found in the multiple mediation models, it does not confirm which mediator contributes to the effect. Therefore, a specific indirect effect with one mediator at a time is tested. To test the mediating effect of inter-functional cohesion in inter-functional interdependency on satisfaction with performance appraisal, a mediation test is done in WarpPLS version 6.0. The regression coefficient of the indirect effect of the mediation $\beta=-0.013$ ( $p=$ 0.358 ). Since insignificance is found, the hypothesis that inter-functional cohesion mediates the influence of functional inter-dependency on satisfaction in performance appraisal is rejected.

The influence of rater competence, inter-functional interdependency on satisfaction with performance appraisal is tested in WarpPLS version 6.0 with rater competence as the only mediator. The $R$-squared is 0.10 , and indirect effect $\beta=-0.091$ $(p=0.004)$. Therefore, it is concluded that rater competence influences the relationship between inter-functional interdependency on satisfaction with performance appraisal. The influence of organizational justice in inter-functional interdependency on satisfaction with performance appraisal is tested in WarpPLS version 6.0 with organizational justice as the only mediator. The $R$-squared is 0.31 , and $\beta=-0.118(p<0.001)$. Thus, the hypothesis that organizational justice mediates the influence of inter-functional interdependency on satisfaction with performance appraisal is accepted. Thus, the higher the organization's organizational justice, the higher the impact of interdependency on satisfaction with performance appraisal. It supports the hypothesis that organizational justice mediates the influence of inter-functional interdependency on satisfaction with performance appraisal. The influence of inter-functional conflict in inter-functional interdependency on satisfaction with performance appraisal is tested in WarpPLS version 6.0 using a mediation model with just inter-functional conflict. The results of the indirect effect is found to be $\beta=-0.015$ ( $p=0.333)$. Since insignificance is found, the hypothesis that inter-functional conflict mediates the influence of functional interdependency on satisfaction in performance appraisal is rejected.

\section{DISCUSSION}

In the past few years, several companies have begun contemplating changes to their performance management systems to gain more value and impact performance (Alder et al., 2016). This indicates that even after many decades of research in performance appraisal, the study on India's real estate industry is still a requirement. It was found that most of the job responsibilities in the real estate industry are not completely independent and do not enjoy autonomy. These job roles are dependent on other factors in the organization. This study's assumption is confirmed by the fact that the job responsibilities are not independent; instead, interdependencies exist in the real estate companies in India. A notable finding of this study is that most of the respondents agreed that they could not predict the input, time of delivery of these inputs to them, and the location they receive the inputs that are required for them to perform. It is evident from this study that the job roles in the real estate companies have a high degree of inter-functional interdependencies.

The inter-functional cohesion in the real estate companies is low. Respondents agreed that the employees in other departments generally are less cooperative, and inputs are difficult to be received. This may be because of the mobility of the teams to the field for construction site and marketing visits. The findings are similar to those of Lee, Lin, $\mathrm{H}$. Huang, W. Huang, and Teng (2015), which showed that task interdependence significantly and positively influenced team cooperation and job performance, and significantly and negatively influenced relationship conflict. Relationship conflict significantly and negatively influenced team co-

Table 7. Multiple mediators and specific indirect effect

\begin{tabular}{l|c|c|c|c:c}
\hline \multicolumn{1}{c}{ Effect } & Multiple mediator & Cohesion & Rater competence & Organizational justice & Conflict \\
\hline Indirect & $-0.236(<0.001)$ & $-0.013(0.358)$ & $-0.091(0.004)$ & $-0.118(<0.001)$ & $-0.015(0.333)$ \\
\hdashline Direct & $-0.123(0.005)$ & $-0.123(0.005)$ & $-0.123(0.005)$ & $-0.123(0.005)$ & $-0.123(0.005)$ \\
\hdashline Total & $-0.359(<0.001)$ & $-0.135(0.002)$ & $-0.214(<0.001)$ & $-0.240(<0.001)$ & $-0.138(0.002)$ \\
\hline
\end{tabular}


operation; task conflict positively and significantly influenced team cooperation. The respondents have a concern about the qualification, knowledge, and understanding of the rater. The respondents agreed that the supervisor or rater who evaluated their performance did not take it seriously or explained them with proper feedback. The employees expressed their concern about the awareness of the rater on the performance appraisal process. The study indicates that employees are uncertain about the rater's effort to impress this group of respondents with their strong knowledge of the performance appraisal process. Roberts and Pregitzer (2007) presented that the employees dislike performance appraisal because managers do not always rate them on objective criteria.

Employees are uncertain about the organization's fairness in conducting the performance appraisal and regarding its regularity. Respondents are concerned about the promotions being unfair. The factors of rater competence and organizational justice are similar to the hygiene factor in motivation, where there will be no satisfaction whatsoever may be the level of fairness on the part of rater and the organization. This is similar to Ibeogu and Ozturen (2015) findings: though they found a positive rating towards justice in performance appraisal, satisfaction with the performance appraisal system was statistically low and non-significant. On the inter-functional conflict among the job roles, there is a possibility that the employees in other functions failed to impress the respondents by the fair behavior strongly enough. Hence, this study clearly shows that the employees' fair behavior and trust in other functions determine the respondents' deliverables and lead to satisfaction with performance appraisal. Functional interdependency was found to impact satisfaction in performance appraisal negatively. This was not a surprise. However, the functional interdependency could only predict around 3\% of the satisfaction in performance appraisal. This highlights that other variables lead to satisfaction in performance appraisal. This is in line with Langfred and Moye's (2004) findings that task autonomy does not always lead to performance and job satisfaction. Similarly, Shaw, Duffy, and Stark (2000) found that interdependence has a congruence effect on group members' satisfaction and performance. The results further throw light that conflict did not have any impact on satisfaction in performance appraisal. Rather Rahim (2017) argued that maintaining a moderate amount of substantive conflict at the individual, group, and intergroup levels are required.

Organizational justice and rater competence had a notable impact on satisfaction in performance appraisal. Cohesion had only a small impact. This reveals that rather than improving the cohesion and reducing the conflict or finding means of right rater competence, the organizational justice matters in the satisfaction in performance appraisal. This can be understood that the cohesion and conflict can be wiped out from the organizational roles, and they are bound to happen when there is a coordinated activity across departments. Executives have understood the factors as part and parcel of their organizational life. Raters are the immediate supervisor to whom the executive is reporting. Therefore, even though the concern on rater competence is one of the factors, executives very well know the problem associated with the rater, and it is beyond the control because the rater is one among them. Executives are looking for an ultimate platform to address their grievances during their performance appraisal and an ear to listen to them. All the intervening variables such as organizational justice, rater competence, inter-functional conflict, and cohesion mediate functional interdependency and performance appraisal satisfaction. This shows that the intervening variables add to satisfaction when there is functional interdependency. However, specific indirect effects for cohesion and conflict were found to be insignificant. Organizational justice and rater competence have individual mediation effects. This result is similar to Chen, $\mathrm{Wu}$, and Leung's (2011) findings that performance appraisals were related to appraisee reactions to the workgroup, which is mediated by goals. They also found that procedural justice strengthened the relationship between goals and performance appraisal.

The real estate industry in India has all the capabilities that can augment the economy of India. The real estate industry's importance is that it has emerged as an employment generator for both educated and uneducated. It is estimated that the real estate industry will grow rapidly in the com- 
ing years. After the RERA implementation, several small and medium-sized companies are slowly fading out. Corporate and big size real estate companies are growing rather rapidly. In India, the real estate industry, which is labor-intensive, can attract more educated people for their career progression. However, in terms of organized business and application of strategic management tools such as performance appraisal, India's real estate industry is still at an emerging stage only. It is reasonable to comment that tens of thousands of rupees are paid out by companies as compensation and rewards based on the performance appraisal process. The accurate performance appraisal process, feedback, and rewards can have long-lasting effects on employees' lives and careers in organizations. It can influence staffing, promotion, and termination decisions besides open avenues to other development opportunities. Hence, understanding performance appraisal outcomes is a serious task required of real estate companies in India.

This study revealed the impact of inter-functional interdependency in real estate companies' job role on satisfaction performance appraisal and noted that it is further mediated by organizational justice and rater competence. The study further points out that organizational justice plays a bigger role than individual raters or evaluators. This study also reveals that though cohesion improves the level of employee satisfaction with appraisal, the conflict has no impact on employee satisfaction with performance appraisal. The findings of this research are in line with the study of Heath and Staudenmayer (2000), which states that the organizations often fail to address the interdependencies through effective coordination and reconfirms the observation that organizational justice can resolve the issues arising out of lack of coordination among the members of various departments in real estate companies. Ilgen et al. (1979) put forth that "if employees are not satisfied or perceive a system as being unfair, they will be less likely to use performance evaluations as feedback to improve their performance".

This study suggests that even if the factors such as inter-functional cohesion or conflict are managed, or there is a problem with the rater competence, employees only look forward to a mechanism within the organization to hear the grievances and address them fairly. To improve organizational justice, one should look into the rating system and reflect the kind of work done. There should be scales to measure the quality and quantity of the work done by the executives. Because of the interdependency and difference in the job role, a different evaluation criterion needs to be established, or there should be some factor score added to each type of job roles based on their interdependencies. There will be a very ambiguous boundary between the good performer and the bad performer. There needs to be an intermediate-range identifying people between good and bad performance and giving people a chance to improve their performance. Many organizational performance appraisals are just an annual routine or a weapon to fire employees. Promotions or increments do not reflect the performance scores, and over time, employees lose faith in the system, leading to dissatisfaction with performance appraisal. There should be explicit implications based on performance scores. The rating is bound to vary with the difference in perception of the rater or due to events in the job role, such as uncontrolled factors, which may affect an individual's outcome. Therefore, a mechanism for representation needs to be in place. Often, employees are left with no feedback throughout the year and are commented on only during the appraisal process, leading to no chance to correct or improve their performance. The review should be frequent and done at different levels. Feedback on the appraisal process, criteria, and the rater needs to be taken for continuous improvement of the appraisal system, making it a fair and effective mechanism.

\section{CONCLUSION}

This study was poised because of the problems of interdependency in the real estate industry and the impact of the same on performance appraisal satisfaction. A conceptual model was developed through a literature review, observation in the real estate companies, and expert inputs. Hypotheses for the study 
were framed from the conceptual model. Data were collected from the executives of the real estate companies through an online survey and were analyzed. The statistical analysis of the data has given clear insight into several problems and prospects of real estate industry and has provided some solutions to solve those problems. Based on this research, recommendations are given to real estate companies in India to improve their organizational justice in conducting accurate and unbiased performance appraisal system in their organizations by improving the cohesion among the employees working in various departments and by considering the role of inter-functional interdependencies in the job role of the employees. Hence, implementing this research study's recommendations becomes imperative and urgent for companies to compete with other industries in attracting talented professionals. A better performance appraisal system is one of the best tools to place the companies in the top ranks in such surveys. The rapid development of better performance appraisal systems in other industries is forcing real estate companies in India to adopt a better performance appraisal system for them.

\section{AUTHOR CONTRIBUTIONS}

Conceptualization: Elangovan N.

Formal analysis: Sridhar Rajendran.

Investigation: Sridhar Rajendran.

Methodology: Elangovan N., Sridhar Rajendran.

Resources: Sridhar Rajendran.

Supervision: Elangovan N.

Validation: Elangovan N.

Visualization: Elangovan N.

Writing - original draft: Sridhar Rajendran.

Writing - review \& editing: Elangovan N.

\section{REFERENCES}

1. Adler, S., Campion, M., Colquitt, A., Grubb, A., Murphy, K., Ollander-Krane, R., \& Pulakos, E. D. (2016). Getting rid of performance ratings: Genius or folly? A debate. Industrial and Organizational Psychology, 9(2), 219-252. Retrieved from https://www.cambridge.org/ core/journals/industrial-andorganizational-psychology/article/ getting-rid-of-performanceratings-genius-or-folly-a-debate/2 15B47ABDD0DEE3B55BE747B8 7FFDCBC

2. Aly, N. A. E. F. M., \& ElShanawany, S. M. (2016). The Influence of Performance Appraisal Satisfaction on Nurses' Motivation and Their Work Outcomes in Critical Care and Toxicology Units. European Scientific Journal, ESJ, 12(20), 119135. Retrieved from https://eujournal.org/index.php/esj/article/ view/7767
3. Arndt, A. D., Karande, K., \& Harkins, J. (2012). Does the performance of other functions in the frontline influence salesperson conflict? International Journal of Retail and Distribution Management, 40(9), 717-736. Retrieved from https://www.researchgate.net/ publication/235250691_Does_ the_performance_of_other_functions_in_the_frontline_influence_salesperson_conflict

4. Bachrach, D. G., Powell, B. C., Bendoly, E., \& Richey, R. G. (2006). Organizational citizenship behavior and performance evaluations: Exploring the impact of task interdependence. Journal of Applied Psychology, 91(1), 193. Retrieved from https://pubmed. ncbi.nlm.nih.gov/16435949/

5. Baethge, A., \& Rigotti, T. (2013). Interruptions to workflow: Their relationship with irritation and satisfaction with performance, and the mediating roles of time pressure and mental demands. Work \& Stress, 27(1), 43-63. Retrieved from https:// www.researchgate.net/publication/263688313_Interruptions_ to_workflow_Their_relationship_with_irritation_and_satisfaction_with_performance_and_the_ mediating_roles_of_time_pressure_and_mental_demands

6. Bobot, L. (2011). Functional and dysfunctional conflicts in retailer-supplier relationships. International Journal of Retail and Distribution Management, 39(1), 25-50. https://doi. org/10.1108/09590551111104468

7. Boswell, W. R., \& Boudreau, J. W. (2000). Employee satisfaction with performance appraisals and appraisers: The role of perceived appraisal use. Human Resource Development Quarterly, 11(3), 283-299. Retrieved from https:// psycnet.apa.org/doi/10.1002/1532- 
1096(200023)11:3\%3C283::AIDHRDQ6\%3E3.0.CO;2-3

8. Brass, D. J. (1981). Structural relationships, job characteristics, and worker satisfaction and performance. Administrative Science Quarterly, 26, 331-348. Retrieved from https://www.jstor. org/stable/2392511?seq=1

9. Cardy, R. L., \& Dobbins, G. H. (1994). Performance appraisal: The influence of liking on cognition. Advances in managerial cognition and organizational information processing, 5, 115-140. Retrieved from https://ijol.cikd.ca/ article_60464_e664300a56883a0e6b8a49a754f0bd81.pdf

10. Chen, T., Wu, P., \& Leung, K. (2011). Individual performance appraisal and appraisee reactions to workgroups: The mediating role of goal interdependence and the moderating role of procedural justice. Personnel Review, 40(1), 87-105. Retrieved from https:// www.researchgate.net/publication/235281953_Individual_performance_appraisal_and_appraisee_reactions_to_workgroups_ The_mediating_role_of_goal_interdependence_and_the_moderating_role_of_procedural_justice

11. Cook, J., \& Crossman, A. (2004). Satisfaction with performance appraisal systems A study of role perceptions. Journal of Managerial Psychology, 19(5), 526-541. https://doi. org/10.1108/02683940410543605

12. Cropanzano, R., Prehar, C. A., \& Chen, P. Y. (2002). Using social exchange theory to distinguish procedural from interactional justice. Group and Organization Management, 27(3), 324-351. Retrieved from https://www.researchgate.net/ publication/247738270_Using_Social_Exchange_Theory_to_ Distinguish_Procedural_From_ Interactional_Justice

13. De Dreu, C. K., \& Van Vianen, A. E. (2001). Managing relationship conflict and the effectiveness of organizational teams. The International Journal of Industrial, Occupational and Organizational Psychology and Behavior, 22(3), 309-328. Retrieved from https://www.jstor. org/stable/3649599? seq=1

14. DeNisi, A. S., \& Murphy, K. R. (2017). Performance appraisal and performance management: 100 years of progress? Journal of Applied Psychology, 102(3), 421. https://psycnet.apa.org/ doi/10.1037/apl0000085

15. Derozier, C. (2003). Marketing creativity in new product development: the role of market orientation, technology orientation, and interfunctional coordination (Ph.D. Thesis). Texas Tech University, Lubbock, USA. Retrieved from https://www. worldcat.org/title/marketingcreativity-in-new-product-development-the-role-of-market-orientation-technology-orientationand-interfunctional-coordination/ oclc/52912349

16. Deutsch, M. (1949). A theory of cooperation and competition. Human relations, 2(2), 129152. https://doi.org/10.1177\% 2F001872674900200204

17. Erdogan, B. (2002). Antecedents and consequences of justice perceptions in performance appraisals. Human Resource Management Review, 12(4), 55578. https://doi.org/10.1016/S10534822(02)00070-0

18. Greenberg, J. (1986). Determinants of perceived fairness of performance evaluations. Journal of Applied Psychology, 71(2), 340-342. Retrieved from https://citeseerx. ist.psu.edu/viewdoc/download?d $\mathrm{o}=10 \cdot 1.1 .464 .8544 \& \mathrm{rep}=\mathrm{rep} 1 \& \mathrm{t}$ ype $=$ pdf

19. Gully, S. M., Devine, D. J., \& Whitney, D. J. (1995). A metaanalysis of cohesion and performance: Effects of level of analysis and task interdependence. Small Group Research, 26(4), 497-520. https://doi.org/10.1177\%2F1046496412468069

20. Heath, C., \& Staudenmayer, N. (2000). Coordination neglect: How lay theories of organizing complicate coordination in organizations. Research in Organizational Behavior, 22,
153-191. https://doi.org/10.1016/ S0191-3085(00)22005-4

21. Hoffman, B. J., \& Woehr, D. J. (2009). Disentangling the meaning of multisource performance rating source and dimension factors. Personnel Psychology, 62(4), 735-765. Retrieved from https://www.researchgate.net/ publication/229565554_Disentangling_the_meaning_of_multisource_feedback_source_and_dimension factors

22. Ibeogu, P. H., \& Ozturen, A. (2015). Perception of justice in performance appraisal and effect on satisfaction: Empirical findings from Northern Cyprus Banks. Procedia Economics and Finance, 23, 964-969. https://doi.org/10.1016/S22125671(15)00359-7

23. Ilgen, D. R., Fisher, C. D., \& Taylor, M. S. (1979). Consequences of individual feedback on behavior in organizations. Journal of Applied Psychology, 64(4), 349. Retrieved from https://psycnet. apa.org/record/1980-28998-001

24. Jacobs, G., Belschak, F. D., \& Den Hartog, D. N. (2014). (Un) ethical behavior and performance appraisal: the role of affect, support, and organizational justice. Journal of Business Ethics, 121(1), 63-76. Retrieved from https:// link.springer.com/article/10.1007/ s10551-013-1687-1

25. Jawahar, I. M. (2006). Correlates of Satisfaction with Performance Appraisal Feedback. Journal of Labour Research, XXVII(2), 213-236. Retrieved from https:// www.researchgate.net/publication/24096463_Correlates_of_Satisfaction_with_Performance_Appraisal_Feedback

26. Kampkötter, P., \& Marggraf, K. (2015). Do employees reciprocate to intra-firm trainings? An analysis of absenteeism and turnover rates. The International Journal of Human Resource Management, 26(22), 2888-2907. https://doi.org/10.1080/09585192. 2015.1005655

27. Keeping, L. M., \& Levy, P. E. (2000). Performance appraisal reactions: Measurement, 
modeling, and method bias. Journal of Applied Psychology, 85(5), 708-723. Retrieved from https://www.researchgate.net/ publication/12271854_Performance_appraisal_reactions_Measurement_modeling_and_method_bias_Journal_of_Applied_Psychology_85_708-723

28. Krejcie, R. V., \& Morgan, D. W. (1970). Determining sample size for research activities. Educational and Psychological Measurement, 30(3), 607-610. https://doi.org/10. 1177\%2F001316447003000308

29. Kuvaas, B. (2006). Performance appraisal satisfaction and employee outcomes: mediating and moderating roles of Swork motivation. The International Journal of Human Resource Management, 17(3), 504-522. https://doi. org/10.1080/09585190500521581

30. Langfred, C. W., \& Moye, N. A. (2004). Effects of task autonomy on performance: an extended model considering motivational, informational, and structural mechanisms. Journal of Applied Psychology, 89(6), 934. Retrieved from https://pubmed.ncbi.nlm.nih. gov/15584833/

31. Le Meunier-FitzHugh, K., \& Piercy, N. F. (2010). Improving the relationship between sales and marketing. European Business Review, 22(3), 287-305. Retrieved from https://www.researchgate. net/publication/235277618_Improving_the_relationship_between_sales_and_marketing

32. Lee, C. C., Lin, Y. H., Huang, H. C., Huang, W. W., \& Teng, H. H. (2015). The effects of task interdependence, team cooperation, and team conflict on job performance. Social Behavior and Personality: an International Journal, 43(4), 529-536. Retrieved from https://www.researchgate. net/publication/277728153_The_ Effects_of_Task_Interdependence_ Team_Cooperation_and_Team_ Conflict_on_Job_Performance

33. McDowall, A., \& Fletcher, C. (2004). Employee development: an organizational justice perspective. Personnel Review, 33(1), 8-29.
Retrieved from https://www.

researchgate.net/publica-

tion/243460816_Employee_development_An_organizational_justice_perspective

34. Messmer, M. (2004). Developing effective performance reviews. Strategic Finance, 85(9), 13-14. Retrieved from https://sfmagazine.com/wp-content/uploads/ sfarchive/2004/03/CAREERS-Developing-effective-performancereviews.pdf

35. Murphy, K. R., \& Balzer, W. K. (1986). Systematic distortions in memory-based behavior ratings and performance evaluations: Consequences for rating accuracy. Journal of Applied Psychology, 71(1), 39. Retrieved from https:// psycnet.apa.org/doi/10.1037/00219010.71.1.39

36. Neyaz, I. (2016). Why the Real Estate Industry Needs Performance Management. Retrieved from https://esconsulting.com.sa/performance/ related-resources-performance/ performance-real-estate/why-thereal-estate-industry-needs-performance-management/

37. Othman, N. (2014). Employee performance appraisal satisfaction: the case evidence from Brunei's civil service (A thesis submitted to the University of Manchester for the degree of Doctor of Philosophy in the Faculty of Humanities. Institute for Development Policy and Management).

38. Palaiologos, A., Papazekos, P., \& Panayotopoulou, L. (2004). Organizational justice and employee satisfaction in performance appraisal. Journal of European Industrial Training, 35(8), 826-840. Retrieved from https://www.researchgate.net/publication/235268111_Organizational_justice_and_employee_satisfaction_in_performance_appraisal

39. Buehler, L. M. (2006). Due process dimensions of performance appraisal, perceptions of organizational justice and some outcomes (Ph.D. Thesis). DePaul University Department of Psychology College of Liberal Arts and Sciences, Chicago.
40. Panggabean, M. (2001). Impact of perceived justice in performance appraisal on work attitudes and performance (Tesis Peringkat Doktor Falsafah). The Nova Southeastern University.

41. Parasher. (2016). India Inc may see attrition rates as high as $31 \%$. Retrieved from https:// www.business-standard.com/ article/companies/india-incmay-see-attrition-rates-as-highas-31-112050100097_1.html

42. Pettijohn, L. S., Parker, S. R., Pettijohn, C. E., \& Kent, O. L. (2001). Performance appraisals: usage, criteria and observations. Journal of Management Development, 20(9), 754771. https://doi.org/10.1108/ EUM0000000006159

43. Rahim, M. A. (2017). Managing conflict in organizations. Westport, US: Routledge.

44. Roberts, G., \& Pregitzer, M. (2007). Why employees dislike performance appraisals. Regent Global Business Review, 1(1), 1421.

45. Sabeen, Z., \& Mehbob, A. A. A. (2008). Perceived fairness of and satisfaction with employee performance appraisal and its impact on overall job satisfaction. The Business Review, 10(2), 185192.

46. Shaw, J. D., Duffy, M. K., \& Stark, E. M. (2000). Interdependence and preference for group work: Main and congruence effects on the satisfaction and performance of group members. Journal of Management, 26(2), 259-279. https://doi.org/10.1016/S01492063(99)00045-8

47. Sun, K. (2011). Inter-unit conflict, conflict resolution methods, and post-merger organizational integration in healthcare organizations (Ph.D. Thesis). University of Minnesota, Minneapolis, USA.

48. Tang, T. L. P., \& Sarsfield-Baldwin, L. J. (1996). Distributive and procedural justice as related to satisfaction and commitment. Paper presented at Annual Meeting of the Southwestern 
Psychological Association (Houston, TX, April 1996).

Retrieved from https://www. researchgate.net/publication/234119067 Distributive and Procedural_Justice_as_Related_to_ Satisfaction_and_Commitment

49. Taylor, M. S., Tracy, K. G., Renard, M. K., Harrison, J. K., \& Carroll, S. J. (1995). Due process in performance appraisal: A quasiexperiment in procedural justice. Administrative Science Quarterly, 40(3), 495-523. Retrieved from https://www.jstor.org/stable/2393795

50. Thurston, P. W., \& McNall, L. (2010). Justice perceptions of performance appraisal practices. Journal of Managerial Psychology, 25, 201-228. Retrieved from https://www.researchgate.net/ publication/235255223_Justice_ perceptions_of_performance_appraisal_practices

51. Tjosvold, D. (1991). Rights and responsibilities of dissent: Cooperative conflict. Employee Responsibilities and Rights Journal, 4(1), 13-23. Retrieved from https:// www.researchgate.net/publication/226534535_Rights_and_Responsibilities_of_Dissent_Cooperative_Conflict

52. Van der Vegt, G. S., \& Janssen, O. (2003). Joint impact of interdependence and group diversity on innovation. Journal of Management, 29(5), 729751. https://doi.org/10.1016\%2 FS0149-2063_03_00033-3

53. Walsh, M. B. (2003). Perceived fairness of and satisfaction with employee performance appraisal (Ph.D. Thesis). The Louisiana State University, Baton Rouge, USA.
54. Wilmot, W. W., \& Hocker, J. L. (2001). Interpersonal conflict. New York: McGraw-Hill.

55. Woehr, D. J., Sheehan, M. K., \& Bennett Jr, W. (2005). Assessing measurement equivalence across rating sources: A multitraitmultirater approach. Journal of Applied Psychology, 90(3), 592-600. Retrieved from https://www.researchgate.net/ publication/7831810_Assessing_Measurement_Equivalence_ Across_Rating_Sources_A_Multitrait-Multirater_Approach

56. Xie, J., Song, X. M., \& Stringfellow, A. (1998). Inter-functional conflict, conflict resolution styles, and new product success: A four-culture comparison. Management Science, 44(12-part-2), 192-206. Retrieved from https://pubsonline.informs. org/doi/10.1287/mnsc.44.12.S192 